\title{
Effect of Water Regimes and Organic Matter Strategies on Mitigating Green House Gas Emission from Rice Cultivation and Co-benefits in Agriculture in Vietnam
}

\author{
Thuy Nguyen Thu, Loan Bui Thi Phuong, Trinh Mai Van, and Son Nguyen Hong
}

\begin{abstract}
Agriculture sector in Vietnam is not only affected by climate change but it also emits a high proportion of greenhouse gas (GHG) - especially rice, which is the main source of GHG emissions in this sector. Many GHG mitigation options have been transferred to rice cultivation in the world with biochar measure, compost measure and applying Alternative Wet and Dry (AWD) measures having high potential to reducing GHG emissions. This study assesses the co-benefits of greenhouse gas emission mitigation options above in comparison with traditional farmers' practice (applying flooding irrigation (PF) in combination with farmyard manure fertilizer (FYM)) to find a climate-smart agriculture system for Vietnam ensuring both economic benefits and maintain Global Warming Potential. Therefore, a field experiment was conducted in Hanoi city, located in Northwest Vietnam. The experiment was divided into two blocks with different water regimes: AWD and PF. Each block was designed with four different types of fertilizer: 1) NPK (i.e. irorganic fertilizer) only; 2) NPK and FYM; 3) NPK and straw compost; and 4) NPK and straw biochar. The result showed that rice yield was significantly different among mitigation treatments compared to traditional farming practise. In addition, the block with AWD irrigation method and NPK+ straw biochar fertilizer showed potential to mitigate GHG emissions significantly with $53.4 \% \quad \mathrm{CO}_{2} \mathrm{eq}$ per grain yield reduction compared to traditional farmers' practice. Furthermore, this mitigation option also helped to save $43.24 \%$ of water irrigation, increase soil fertilit and reuse Vietnam's agricultural residue.
\end{abstract}

Index Terms - Rice paddy field, biochar, compost, AWD, climate-smart agriculture system.

\section{INTRODUCTION}

Agriculture has been not only damaged by climate change but also contributed a big Green House Gases (GHG) emission in total national GHG inventory [1]. According to World Bank (2007) [2], climate change affected about $1 \%$ GDP and the livelihood of residences in Vietnam.

MONRE (2012) [3] shows that if sea level rise at 1 meter up to $2100,38.9 \%$ of natural land area and $32.16 \%$ of agricultural land areas will be lost in Mekong River Delta Region. This lead to total rice quantity in MRD will be

Manuscript received October 30, 2014; revised May 12, 2015. This work was supported in part by National Foundation for Science and Technology Development of Vietnam (NAFOSTED) under grant from project 105.09-2011.21.

Thuy Nguyen Thu is with Graduate School of Life Science, Tsukuba University, Japan (e-mail: thuynt1112@gmail.com).

Trinh Mai Van, Loan Bui Thi Phuong, and Son Nguyen Hong are with Institute for Agricultural Environment, Ministry of Agriculture and Rural Development, Vietnam. reduced by approximately $40.52 \%$ (9.52 million ton of rice), as a result, "Vietnam will be no longer rice exportation country and threaten to domestic food security" [4]. One reason for this phenomenon is the increase of Green House Gas (GHG) emission by human activities, such as the emission of $\mathrm{CH}_{4}$ and $\mathrm{N}_{2} \mathrm{O}$ from agriculture, especially $\mathrm{CH}_{4}$ from rice base systems. Vietnam has more than 7 million ha of rice cultivation with continuous flooding irrigation, the amount of $\mathrm{CH}_{4}$ and $\mathrm{N}_{2} \mathrm{O}$ emission are estimated very large. According to second communication on national GHG inventory [1], GHG emission from agriculture was estimated about 65.9 million ton $\mathrm{CO}_{2}$ equivalent $\left(\mathrm{CO}_{2} \mathrm{e}\right)$, comprised to $43.1 \%$ of total national GHG emission. Therefore, reducing emission of these gases will significantly contribute to mitigating climate change. Many researches in the world have showed that we can reduce the emission of GHG throughout agricultural activities as using dicyandiamide to limit the transforming process from ammonium to nitrate and reduce emission of $\mathrm{N}_{2} \mathrm{O}$ [5]. Previous research also showed that in China and India, the fammers applied different farming techniques, for example, shifting from paddy rice to dry land rice; reducing flooding level in the rice field; applying ammonium sulphate fertilizer; middle season drainage; returning rice straw intercrop; applying slow release fertilizer compare with the conventional farming techniques of always flooding to reduce GHG emission [6], [7]. However, in Vietnam the study on GHG emission from rice cultivation and mitigation measures are limited. Vietnam has already signed on the Kyoto protocol on reduction of GHG emission for climate change mitigation. In order to carry out this mission, the government asked all sectors to apply the advanced technologies, implement more production procedure guidelines, especially rice cultivation sub-sector- a largest emission one. In addition, after COP16 conference in Copenhagen, Denmark, Vietnam Agriculture and Rural development minister Cao Duc Phat has promised to reduce GHG emission from agriculture up to $20 \%$ in 2020 . Therefore, my objective of my research is to calculate GHG emission from different mitigation options to find out the most effective farming practice with a low cost, environmental protection and ensuring GHG emission reduction for fammers in Vietnam in order to achieve the goal of Ministry of Agricultural and rural development.

\section{MATERIALS AND METHODS}

\section{A. Experiment Site}

The research was conducted in Thanh Tri district of Hanoi 
$\left(20^{\circ} 55^{\prime} 60^{\prime \prime} \mathrm{N}\right.$ and $105^{\circ} 50^{\prime} 54^{\prime \prime} \mathrm{E}$, elevation $\left.3 \mathrm{~cm}-4 \mathrm{~cm}\right)$ during summer season 2012. The climate in Thanh Tri district is humid tropical with the mean annual temperature in summer season is $33{ }^{\circ} \mathrm{C}$. The soil had the same characteristic to the
Red River Alluvial soil with slightly acidic $\left(\mathrm{pH}_{\mathrm{KCK}}=5.07\right)$, and containing $2.62 \%$ of orangic $C$ and a high $0.25 \%$ total of $N$ according Table I.

\begin{tabular}{ccccccc}
\multicolumn{5}{c}{ TABLE I: SOIL PROPERTITIES BEFORE EXPERIMENT } \\
\hline $\begin{array}{c}\text { Soil horizon } \\
\text { thickness }(\mathrm{cm})\end{array}$ & $\begin{array}{c}\text { Bulk } \\
\text { Density }\left(\mathrm{g} / \mathrm{cm}^{3}\right)\end{array}$ & $\begin{array}{c}\text { Particle } \\
\text { Density }\left(\mathrm{g} / \mathrm{cm}^{3}\right)\end{array}$ & Porosity $(\%)$ & & Particle size (\%) \\
$0-15$ & 1.37 & 2.60 & 49 & Sand & Limon & Clay \\
& & & 49.0 & 50.2 & 26.8 \\
\hline
\end{tabular}

\section{B. Experiment Design}

For the summer rice crop in this experiment, the rice variety is Oryza sativa L. indica, and experimental activities of field experiment are summarized in Table II.

\begin{tabular}{|c|c|c|}
\hline \multicolumn{3}{|c|}{ TABLE II: EXPERIMENTAL ACTIVITIES } \\
\hline Ord & Activities & Date \\
\hline \multirow[t]{5}{*}{1} & Farming activities & \\
\hline & Rice variety preparation & 19 July \\
\hline & - Sowing & 22 July \\
\hline & - Transplanting: & 5 August \\
\hline & - Havesting: & 30 October \\
\hline \multirow[t]{4}{*}{2} & Fertilizer & \\
\hline & - Base application & 5 August \\
\hline & - First top dressing & 20 August \\
\hline & - Second top dressing & 5 September \\
\hline \multirow[t]{2}{*}{3} & Measurement & \\
\hline & $\begin{array}{l}\text { Plant height, Soil and water } \\
\text { environment dynamic: water } \\
\text { depth, air, water and soil } \\
\text { temperature, soil and water } \mathrm{pH} \text {, } \\
\text { soil and water EC, soil and water } \\
\text { Eh. }\end{array}$ & Every week \\
\hline \multirow[t]{4}{*}{4} & Sampling & \\
\hline & -Gas sampling & Every week \\
\hline & - Plant sampling & When haverting \\
\hline & - Soil sampling & $\begin{array}{l}\text { Before cultivation, in the } \\
\text { time of taking air } \\
\text { sampling and after } \\
\text { haverting }\end{array}$ \\
\hline 5 & Gas sampling analysis & $10-12 / 2012$ \\
\hline
\end{tabular}

Rice was transplanted in paddy field with $2-3$ seedlings per hill and with $20 \mathrm{~cm} \times 20 \mathrm{~cm}$ spacing between hills. The experiment was designed with 8 treatments using a block Randomized Complete Block (RCB) with triplicates on a plot size $4 \mathrm{~m} \times 5 \mathrm{~m}$ each. There were two water regimes including permanent flooding (PF) and Alternative Wetting and Drying
(AWD) with four types of feritilizer being mineral fertilizer (NPK) was applied equally for all treatment, farmyard manure fertilizer (FYM), straw biochar fertilizer (BC) and straw compost fertilizer (COM). Only NPK was used as fertilizer in control treatments. These treatments are described in Table III.

The water regimes were controlled differently in each block. In PF block, water level was kept at $3-5 \mathrm{~cm}$ above soil surface starting from one week before transplanting until 15 days before harvest. In AWD block, water level was maintained according water saving techniques from Wassman in IRRI [8].

\begin{tabular}{ccc}
\multicolumn{2}{c}{ TABLE III: TREATMENTS IN EXPERIMENTAL SITE } \\
\hline $\begin{array}{c}\text { Tater } \\
\text { regimes }\end{array}$ & $\begin{array}{cc}\text { T. PF irrigation } \\
\text { PF control }\end{array}$ & b. AWD irrigation \\
Fertilizers & AW- FYM & AWD- FYM \\
& PF-COM & AWD-COM \\
& PF-BC & AWD-BC \\
\hline
\end{tabular}

There were three times for fertilizer. The first time was base application with FYM/Biochar/compost, 30\% nitrogen and $100 \%$ phosphorus. The next time was first split application (10 days after transplating) with 50\% $N+50 \%$ $\mathrm{K}_{2} \mathrm{O}$ and the last time was second split application (Particle Initiation): $20 \% \mathrm{~N}+50 \% \mathrm{~K}_{2} \mathrm{O}$. The equal amount of $\mathrm{C}$ input $\left(1000 \mathrm{~kg} \mathrm{ha}^{-1}\right)$ was used for each treatment with organic fertilizer in Table IV. In addition, the amount of mineral fertilizer for all treatments was used as similarly as that for fammer's farming practise with $80\left(\mathrm{~kg} \mathrm{ha}^{-1}\right) N+60(\mathrm{~kg}$ $\left.\mathrm{ha}^{-1}\right) \mathrm{P}_{2} \mathrm{O}_{5}+40\left(\mathrm{~kg} \mathrm{ha}^{-1}\right) \mathrm{K}_{2} \mathrm{O}$.

TABLE IV: PROPERTIES OF ORGANIC FERTILIZER APPLIED

\begin{tabular}{ccccccc}
\multicolumn{7}{c}{ TABLE IV: PROPERTIES OF ORGANIC FERTILIZER APPLIED } \\
\hline Organic amendments & Humidity $(\%)$ & $\%$ C content & $N(\%)$ & $P(\%)$ & $K(\%)$ & ${\text { C input }\left(\mathrm{kg} \mathrm{ha}^{-1}\right)}_{\text {Farmyard manure }}$ \\
72.3 & 31.34 & 0.65 & 0.91 & 0.6 & 1000 \\
Biochar from rice straw & 78.07 & 35.32 & 1.21 & 0.12 & 1.81 & 1000 \\
Compost & 37.89 & 20.95 & 0.19 & 0.38 & 0.72 & 1000 \\
\hline
\end{tabular}

\section{Gas Sampling Analytical Methods}

The closed chamber technique as described by Zhang et al. (2010) [7] was used to take gas sampling. The chamber includes two main parts. The first part is a chamber fixing foot made from a stainless steel $36 \mathrm{~cm}$ wide, $40 \mathrm{~cm}$ long and $35 \mathrm{~cm}$ high. The second is a closed-top chamber made by transparent Plexiglas with dimession $36 \mathrm{~cm}$ wide, $40 \mathrm{~cm}$ long and $95 \mathrm{~cm}$ high. A thermometer to measure temperature and two small electric fans to homogenize air during gases sampling were fixed inside the top chamber. The fans were connected with disposable batteries placed on the top of the chamber within a case to supply power. The top chamber also contained a $3 \mathrm{~mm}$ hole on the top. An open ended plastic tube with $3 \mathrm{~mm}$ diameter and $1 \mathrm{~m}$ length was inserted into the chamber through the hole with one end hanging $50 \mathrm{~cm}$ inside and the other end protruding $50 \mathrm{~cm}$ outside the top chamber. The hole was sealed from periphery after the tube insertion so as to 
prevent air leakage. A check valve was provided on the protruding part of the tube to control the gases flow during gases sampling.

The calculation of emission was based on the change in gas concentrations within the chamber's enclosed in a period from 0 minute to 30 minute for each sampling. Equation by Pihlatie, 2013 [9] was used to calculate the amount of $\mathrm{CH}_{4}$ and $\mathrm{N}_{2} \mathrm{O}$ emission per hour $\left(F=\mathrm{mg} / \mathrm{m}^{2} / \mathrm{h}\right)$ :

$$
F=\frac{S \frac{M}{V m} \times \frac{V}{A} \times \frac{273.16}{T+273.16} \times 3600}{1000}
$$

where $S$ is the slope of the linear at chamber closure ( $\mathrm{ppm} / \mathrm{s}$ ), $M$ is the mocule weight of the gas of interest in which $\mathrm{CH}_{4}$ and $\mathrm{N}_{2} \mathrm{O}$ being $16,042 \mathrm{~g} / \mathrm{mol}$ and $44,0128 \mathrm{~g} / \mathrm{mol}$ respectively, $V$ is the chamber volume $\left(\mathrm{m}^{3}\right), V m$ is the volume of the ideal gas $\left(0.0024 \mathrm{~m}^{3} / \mathrm{mol}\right)$ and $T$ is the temperature inside the chamber $\left({ }^{0} \mathrm{C}\right)$. The cumulative emission of $\mathrm{CH}_{4}$ and $\mathrm{N}_{2} \mathrm{O}$ from transplanting to before harvesting 15 days was calculated from the area under curve each mesurement time point as Fig. 1 below and equation 2 .

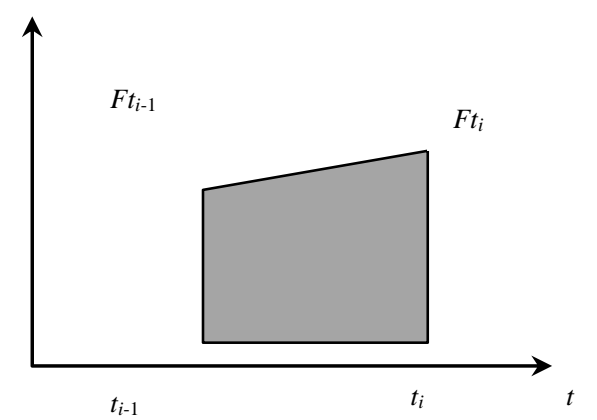

Fig. 1. The area of two adjacent intervals.

$$
A t\left(_{i-1, i}\right)=\left(t_{i-1}-t_{i}\right) \times\left(F t_{i-i}+F t_{i}\right) \div 2
$$

where $A t\left({ }_{i-1, i}\right)$ is the area of two adjacent intervals (between $t_{i-1}$ and $\left.t_{i}\right), t_{i-1}$ and $t_{i}$ are two dates of measurements corespondently. $F t_{i-1}$ và $F t_{i}$ are the fluxes of $\mathrm{CH}_{4}$ or $\mathrm{N}_{2} \mathrm{O}$ at the two measurement date above.

Therefore, the cumulative gas emission was calculated by equation as followed:

Cumulative emission:

$$
\mathrm{CH}_{4} \text { or } \mathrm{N}_{2} \mathrm{O}=\sum A t(i-1, i)
$$

The following equation was used to calculate total amount of $\mathrm{CH}_{4}$ or $\mathrm{N}_{2} \mathrm{O}$ emission during all season (where $\Delta d$ is the total days from transplanting to havesting):

$\mathrm{N}_{2} \mathrm{O}\left(\mathrm{mgN} / \mathrm{m}^{2} /\right.$ season $)=\sum \mathrm{N}_{2} \mathrm{O}\left(\mathrm{mgN} / \mathrm{m}^{2} / \mathrm{hr}\right) \times 24$ hours $\times \Delta \mathrm{d}$

\section{Statistic Method}

Statistical analyses of data were conducted by SAS 9.1 model. The impact of different rice cultivation option on $\mathrm{CH}_{4}$, $\mathrm{N} 2 \mathrm{O}$ emission and $\mathrm{CO}_{2}$ equivalent per rice grain were investigated by one-way ANOVA. Using Duncan (alpha=
$0 \cdot 05)$ post-hoc test for multiple comparisons if appearing the significance of the treatment effect.

\section{RESULTS AND DISCUSSION}

\section{A. Soil Properties Improvement}

The result showed that some of soil properties were improved in Table $\mathrm{V}$.

In table below, $\mathrm{pHKCl}$ after treatment increased from 0.38 to 0.85 compared to before treatment. Organic matter in soil of treatments after experiment rose compared to that before experiment fluctuating from $24.5 \%$ to $65 \%$ depending on each treatment. The lowest increase was in mineral fertilizer treatments and the highest was in biochar treatments followed by FYM treatments. Carbon exchange capacity (CEC) is proportional to the organic carbon in the soil. There were no significantly difference in organic carbon in soil between PF

\begin{tabular}{|c|c|c|c|c|}
\hline Treatments & $\mathbf{p H}_{\mathrm{KCl}}$ & $N(\%)$ & $\mathrm{OC}(\%)$ & $\begin{array}{c}\text { CEC } \\
\text { (cmolc/kg) }\end{array}$ \\
\hline Before experiment & 5.07 & 0.103 & 1.255 & 19.20 \\
\hline \multicolumn{5}{|l|}{$\begin{array}{l}\text { After experiment } \\
\text { a. PF irrigation }\end{array}$} \\
\hline PF control & 5.92 & 0.113 & 1.564 & 19.32 \\
\hline PF- FYM & 5.61 & 0.179 & 1.823 & 19.86 \\
\hline PF-COM & 5.65 & 0.157 & 1.679 & 19.59 \\
\hline PF-BC & 5.72 & 0.180 & 2.074 & 20.25 \\
\hline \multicolumn{5}{|l|}{ b. AWD irrigation } \\
\hline AWD control & 5.90 & 0.135 & 1.562 & 19.19 \\
\hline AWD- FYM & 5.45 & 0.192 & 2.070 & 19.92 \\
\hline AWD-COM & 5.86 & 0.176 & 1.754 & 19.50 \\
\hline AWD-BC & 5.84 & 0.192 & 1. 945 & 19.90 \\
\hline
\end{tabular}
irrigation and AWD irrigation block.

TABLE V: SOIL PROPERTIES BEFORE AND AFTER EXPERIMENT

\section{B. Reusing Agricultural Residue}

After haverting, the fammers have burnt agricultural residue directly in farming site [10]. This leads to $\mathrm{CO}_{2}$ emission, air pollution and even affect seriously to residence's health.

According the inversitgation from Institute for Agricultural Environment [10] in Fig. 2, about more than haft of fammers said that they burnt rice residue directly after haverting. So, if the famers reuse agricultural residue for farming activities by using them to making biochar and compost fertilizer. As a result, the community can avoid adverse impacts from burning agricultural residue and obtain economic values from this activity.

Experiment showed that the treatments applying straw biochar, the amount of rice straw residue was used for one ha accounted for 21.6 tons. And the treatments applying straw compost, the amount of rice straw using was 19.5 tons per ha. Therefore, if applying biochar and compost method, the situation of burning agriculture residue especially rice residue will be limited.

\section{Water Saving}

The total of irrigation level of one season is determined by 
the equation [5]: $M=M_{1}+M_{2}$

where:

$M_{1}$ is irrigation level of tillage period;

$M_{2}$ is adding irrigation level for land;

The amount of water usage for irrigation tillage period:

$$
M_{1}=W_{1}+W_{2}+W_{3}+W_{4}-10 \mathrm{CP}\left(\mathrm{m}^{3} / \mathrm{ha}\right) .
$$

The amount of water to saturating the soil cultivation:

$$
\begin{gathered}
W_{1}=10 \times A \times H \times\left(1-\beta_{\mathrm{o}}\right)=10 \times 0.4 \times 300 \times(1-0.6)=480 \\
\left(\mathrm{~m}^{3} / \mathrm{ha}\right) .
\end{gathered}
$$

The amount of water needed to form water layers in field surface: $W_{2}=10 a=300\left(\mathrm{~m}^{3} / \mathrm{ha}\right)$.

Average water layers in field surface in caculation period $(a=30 \mathrm{~mm})$;

The amount of water stabilization soaked in Tillage a:

$$
W_{3}=10 K \times \frac{H+a}{H} \times(T a-T b)\left(\mathrm{m}^{3} / \mathrm{ha}\right)
$$

where $H$ is The depth of soil cultivation layer $(H=300 \mathrm{~mm})$, $T a$ is Time to prepare soil ( $T a=10$ day), $T b$ is time to saturate the soil cultivation layer $(T b=2$ day)

$$
W_{3}=10 \times 2 \times(300+30) / 300 \times(10-2)=176\left(\mathrm{~m}^{3} / \mathrm{ha}\right)
$$

The amount of water evaporation during Tillage:

$$
\begin{gathered}
W_{4}=10 . E T_{\mathrm{o}} . t=10 \times 4.42 \times 10=442\left(\mathrm{~m}^{3} / \mathrm{ha}\right) . \\
M_{1}=W_{1}+W_{2}+W_{3}+W_{4}-10 C P=480+400+176+442 \\
-10 \times 0.6 \times 7.3=1454\left(\mathrm{~m}^{3} / \mathrm{ha}\right) .
\end{gathered}
$$

To determine the amount of evaporation water in field surface(Etc), we applied Penman-Monteith equation [11]

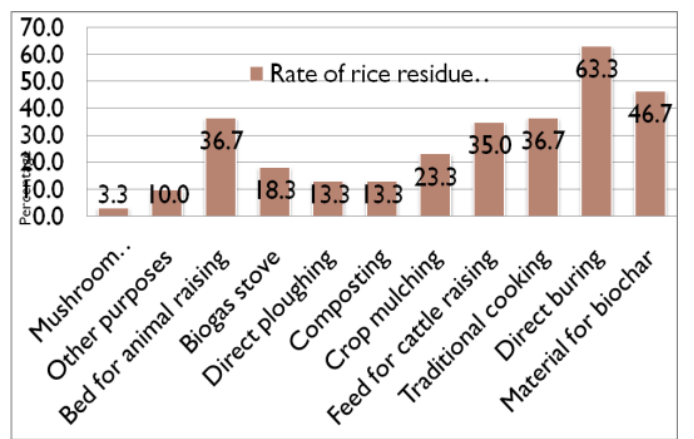

Fig. 2. Multi- purpose of rice residue use in Red River Delta [10].

1) Caculating the amount of water caring irrigarion for rice in summer season 2012 (Permanent floofing irrigation)

Caculation result shown that:

The total amount of water consumption in season:

$$
\Sigma(E T c+K c)=756.77 \mathrm{~mm}=7567.7\left(\mathrm{~m}^{3} / \mathrm{ha}\right)
$$

The total amount of rainwater in season:

$$
\Sigma P=330,08 \mathrm{~mm}=3300.8\left(\mathrm{~m}^{3} / \mathrm{ha}\right)
$$

The total amount of irrigated water in season:

$$
M_{2}=\Sigma(E T c+K c)-\Sigma P=7767.7-3300.8=4266.9\left(\mathrm{~m}^{3} / \mathrm{ha}\right)
$$

The amount of needed water for tillage and caring soil irrigarion:

$$
M_{1}+M_{2}=1454+4266.9=5720.9\left(\mathrm{~m}^{3} / \mathrm{ha}\right)
$$

2) Caculating the amount of water for $A W D$ irrigarion

\begin{tabular}{|c|c|c|c|}
\hline \multirow[b]{2}{*}{ Season } & \multicolumn{3}{|c|}{ Amount water usage $\left(\mathrm{m}^{3} / \mathrm{ha}\right)$} \\
\hline & $\mathrm{PF}$ & AWD & Water saving $(\%)$ \\
\hline $\begin{array}{l}\text { Summer season } \\
2012\end{array}$ & 5720.9 & 3246.92 & 43.24 \\
\hline
\end{tabular}
for rice in summer season 2012

The total amount of water consumption in season:

$$
\Sigma(E T c+K c)=654.72 \mathrm{~mm}=6547.72\left(\mathrm{~m}^{3} / \mathrm{ha}\right)
$$

The total amount of rainwater in season:

$$
\Sigma P=330,08 \mathrm{~mm}=3300.8\left(\mathrm{~m}^{3} / \mathrm{ha}\right) .
$$

The total amount of irrigated water in season:

$$
\begin{gathered}
M_{2}=\Sigma(E T c+K c)-\Sigma P=6547.72-3300.8=3246.92 \\
\left(\mathrm{~m}^{3} / \mathrm{ha}\right) .
\end{gathered}
$$

The amount of needed water for tillage and caring soil

\begin{tabular}{|c|c|c|}
\hline \multirow[b]{2}{*}{ Treatment } & \multicolumn{2}{|c|}{ Summer rice season 2012} \\
\hline & Yield (kg/ha) & $\begin{array}{c}\% \text { increase to } \\
\text { control }\end{array}$ \\
\hline \multicolumn{3}{|l|}{ a. PF irrigation } \\
\hline PF control & $3530(b)^{*}$ & \\
\hline PF- FYM & 4740 (a) & 34.39 \\
\hline PF-COM & 3850 (b) & 9.05 \\
\hline PF-BC & 3810 (b) & 7.91 \\
\hline \multicolumn{3}{|l|}{ b. AWD irrigation } \\
\hline AWD control & 3520 (b) & \\
\hline AWD- FYM & 4490 (a) & 27.36 \\
\hline AWD-COM & $3730(b)$ & 5.83 \\
\hline AWD-BC & $3570(\mathrm{~b})$ & 1.28 \\
\hline
\end{tabular}
irrigarion:

$$
M=M_{1}+M_{2}=1454+3200=4654\left(\mathrm{~m}^{3} / \mathrm{ha}\right) .
$$

TABLE VI: WATER USAGE IN AWD AND PF IRRIGATION

Because experiment was conducted from July to October, this period was rainny season. Both $\mathrm{PF}$ and AWD irrigation block, the amount of irrigated water was very small. Even though, some period of drying to AWD block the water in the field was quite high about $5 \mathrm{~cm}$ and have to bump off water to outside. As Table VI, with AWD treatments, the amount of water saving was about $14.67 \%$ compared to PF treatments.

\section{The Effect of Mitigation Option on Rice Yield}

The result showed the rice yield in summer season 2012 in experimental site as described in Table VII.

TABLE VII: RICE YIELD FROM TREATMENTS

Grain yield was slightly higher in PF irrigation than AWD irrigation with same fertilizer method. In addition, it was also higher in organic fertilizer treatments than mineral fertilizer treatment. However, in both two kinds of irrigation, farmyard 
manure was illustrated by the highest yield in compared to other fertilizers. Among organic fertilizers, the lowest yield under $\mathrm{BC}$ - amended treatment can be explained by the low bioavailability of $\mathrm{N}$ in $\mathrm{BC}$ in comparision with $\mathrm{N}$ in FYM in the first season BC applied. The increase of bioavailability of $\mathrm{N}$ in second season will be stronger and grain yield can improved.

\section{E. Green House Gas Emission}

\section{1) GWP of each treatment}

Based on IPCC 2007, global warming potential (GWP) over a hundred-year period was calculated by converting all to $\mathrm{CO}_{2}$ equivalent and $\mathrm{CH}_{4}$ was converted to $\mathrm{CO}_{2 \mathrm{e}}$ by a coefficient of 25 and the coefficient of $\mathrm{N}_{2} \mathrm{O}$ being 298 [12]. Total green house gas emission was calculated as followed equation:

$$
\begin{aligned}
G W P \mathrm{CO}_{2} \mathrm{e}=\mathrm{CH}_{4}\left(\mathrm{CO}_{2} \mathrm{e}\right) & +\mathrm{N}_{2} \mathrm{O}\left(\mathrm{CO}_{2} \mathrm{e}\right)=\mathrm{CH}_{4} \times 25+\mathrm{N}_{2} \mathrm{O} \\
& \times 298 .
\end{aligned}
$$

According Fig. 3, traditional farming practices (PF-FYM) illustrated the biggest amount of $\mathrm{CO}_{2} \mathrm{eq}$ emission in summer season 2012, whereas, biochar application in both water regimes had a low of $\mathrm{CO}_{2}$ emission in same time.

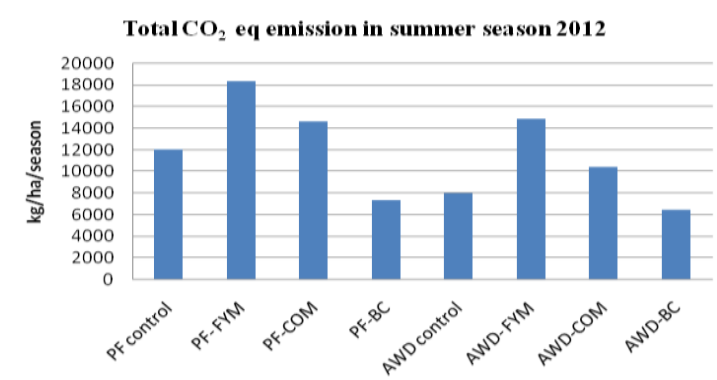

Fig. 3. Total $\mathrm{CO}_{2}$ eq emission as affected by mitigation options.

The $\mathrm{CO}_{2}$ eq emission per kg grain yield was calculated from dividing $\mathrm{GWP} \mathrm{CO}_{2} \mathrm{e}$ by grain yield produced.

The Table VIII presented that FYM fertilizer in both PF water regimes and AWD water regimes had the highest of $\mathrm{CO}_{2} \mathrm{e} / \mathrm{kg}$ grain yield with $3.88 \mathrm{kgCO}_{2} \mathrm{e} / \mathrm{kg}$ grain yield and 3.80 $\mathrm{kgCO}_{2} \mathrm{e} / \mathrm{kg}$ grain yield, corespondently in summer season 2012. In contrast, the AWD-BC showed the lowest $\mathrm{CO}_{2} \mathrm{eq}$ emission per grain yield only $1.81 \mathrm{CO}_{2} \mathrm{e} / \mathrm{kg}$ grain yield reducing $53.4 \%$ and $20.2 \%$ the amount of $\mathrm{CO}_{2}$ eq emission compared to traditional farming practice of farmers (PF-FYM treatment) and AWD control only applying mineral fertilizer, respectively.

TABLE VIII: CUMULATIVE EMISSION OF $\mathrm{CH}_{4}$ AND N $2 \mathrm{O}, \mathrm{GWP} \mathrm{CO}_{2}$ EQ AND $\mathrm{CO}_{2}$ EQ PER KG GRAIN RICE FOR TREATMENTS

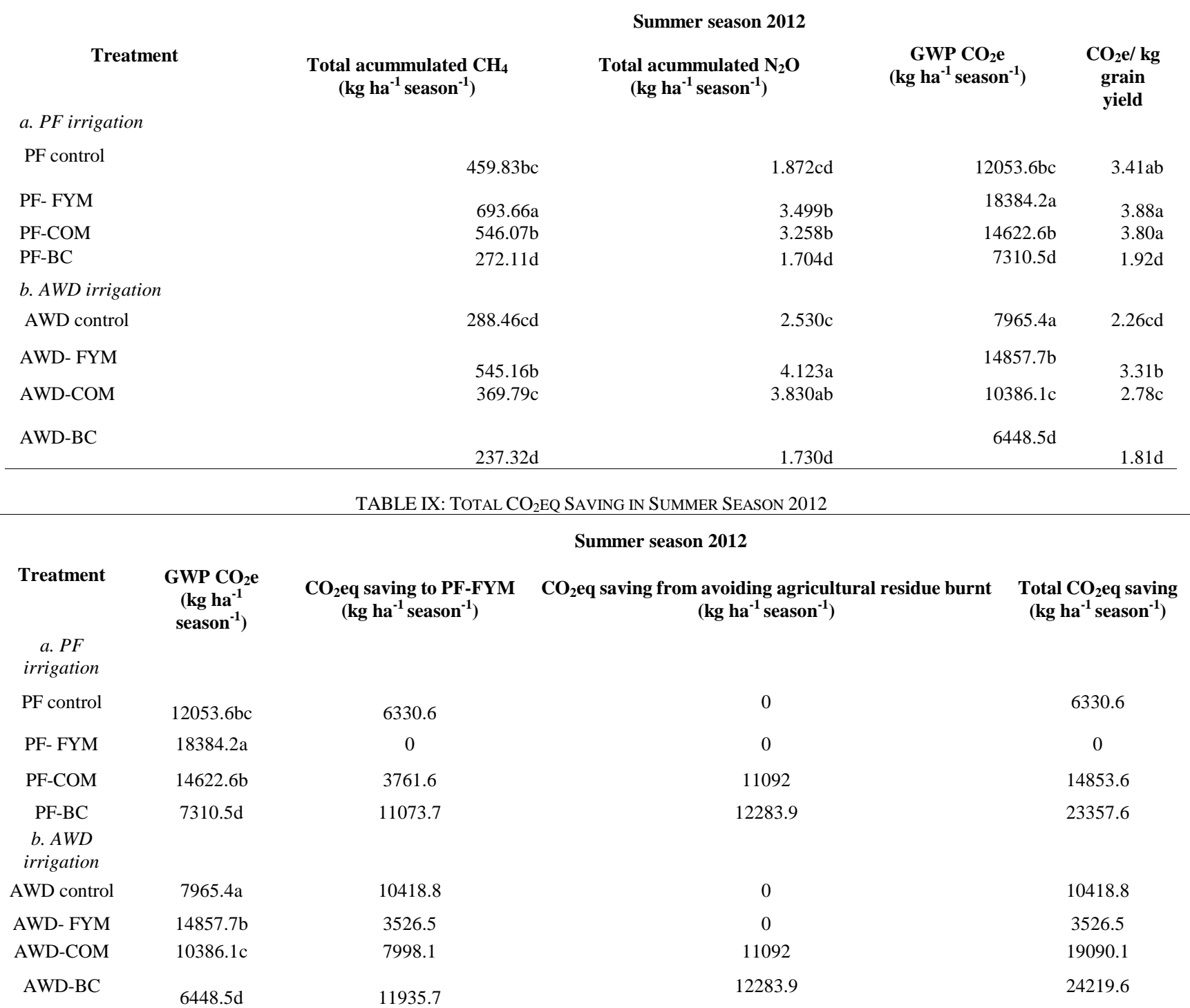


Total emission saving $=$ Emission saving from rice cultivation + emission saving from avoiding agricultural residue burnt.

Therefore, we can calculate the total GHG emission saving when applying mitigation option as following Table IX. We assumed that one ton rice straw burning emitted 1.21ton $\mathrm{CO}_{2} \mathrm{eq}$ and $47 \%$ of rice straw residue be burnt without biochar and compost application [11].

The AWD treatments had a potential in mitigating GHG emission remarkably compared to PF treatment. Especially, the AWD-BC treatment had big amount of $\mathrm{CO}_{2}$ eq saving with $24219.6 \mathrm{~kg} \mathrm{CO}_{2}$ eq saving /ha/season compared to traditional practice of famers.

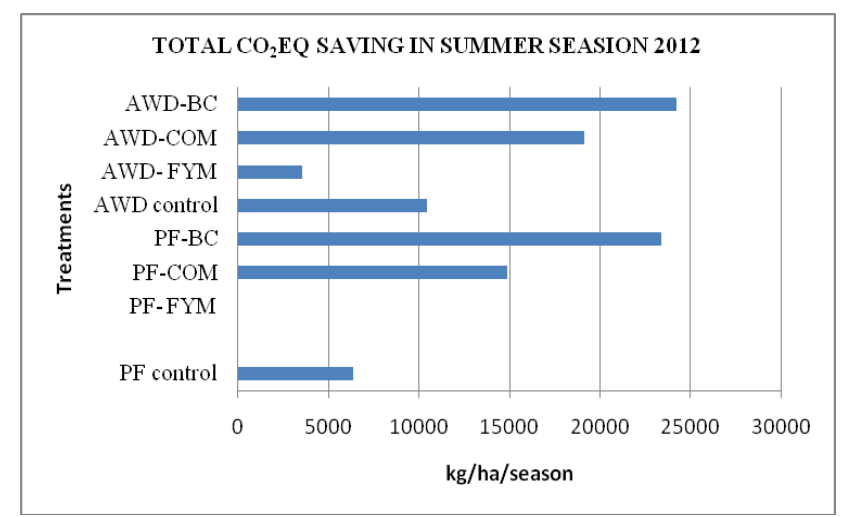

Fig. 4. Total $\mathrm{CO}_{2}$ eq saving when applying mitigation options.

Fig. 4 showed that in same water regimes, the biggesst amount of $\mathrm{CO}_{2}$ eq saving in summer season 2012 was resulted from applying biochar fertilizer, followed by compost fertilizer.

\section{CONCLUSION}

The AWD water regime and organic matter fertilizer such as biochar and compost had potential in reducing $\mathrm{CH}_{4}$ and $\mathrm{N}_{2} \mathrm{O}$ emission compared to traditional practice of famers. Applying AWD water regimes can help save the amount of water irrigated per season by about $43.24 \%$ compared to permanent flooding. Oganic matter fertilizers can help the famer recycled residue and increae soil quality including organic carbon contening and CEC in soil improvement. Suprisingly, the AWD-BC treatment with $1.81 \mathrm{CO}_{2} \mathrm{e} / \mathrm{kg}$ grain yield reduced by $53.4 \%$ and $20.2 \%$ the amount of $\mathrm{CO}_{2} \mathrm{eq}$ emission compared to traditional farming practice of farmers (PF-FYM treatment) and AWD control only using mineral fertilizer, respectively. Besides, the amount of $\mathrm{CO}_{2}$ eq saving when apply AWD-BC practice was very high nearly 2.4 ton/ha/season. From the result of experiment, it can be seen that the most effective mitigation practice for rice cultivation is the AWD in combination with biochar option. This mitigation ensures bringing co-benefits for agriculture sector not only reducing significantly of Green House Gas emission but also improving soil quality and saving irrigation water. However, it takes more time to examine the long-term impact of AWD-BC practice on yield, soil quality and GHG emission.

\section{ACKNOWLEDGMENT}

The authors would like to thank National Foundation for Science and Technology Development of Vietnam (NAFOSTED) for their financial support and Institute of Agricultural Environment, Vietnam for their instruments and tecnicals support.

\section{REFERENCES}

[1] Vietnam's Second National Communication to the United Nations Framework Convention on Climate Change, Ministry of Natural Resources and Environment (MONRE), Hanoi, Vietnam, pp. 70-73, 2010.

[2] S. Dasgupta, B. Laplante, C. Meisner, D. Wheeler, and J. Yan, "The impact of sea level rice on developing country: A comparative analysis," World Bank Policy Research Working Paper 4136, pp. 27-33, 2007.

[3] Climate Change, Sea Level Rise Scenarios for Vietnam, Ministry of Natural Resources and Environment (MONRE), 2009.

[4] T. V. The, "Analysing impacts of climate change on agriculture in Vietnam, proposing adaptation measures and policies to cope with impacts," Project report from Ministry of Agriculture and Rural Development (MARD) and UNDP, Hanoi, Vietnam, pp. 30-40, 2010.

[5] D. Giltrap, Saggar, and H. Wilde, "Using the NZ-DNDC model to estimate agricultural $\mathrm{N}_{2} \mathrm{O}$ emissions in the Manawatu-Wanganui region," Plant and Soil, vol. 309, pp. 191-209, 2008.

[6] B. Jagedeesh, "Modeling of methane emissions from rice-based production systems in India with the denitrification and decomposition model," Field Validation and Sensitivity Analysis Current Science, pp. $1-6,2005$.

[7] A. Zhang, L. Cui, Q. Hussai et al., "Effect of biochar amendment on yield and methan and nitrous oxide emissions from a rice paddy from Tai Lake plain, China," Agriculture, Ecosystems and Environment, vol. 139, no. 4, pp. 469-475, 2010.

[8] R. Wassmann, R. S. Lantin, H. U. Neue, L. V. Buendia, T. M. Corton, and Y. Lu, "Characterization of methan emissions from rice fields in Asia," Nutrient Cycling in Agroecosystems, vol. 58, ch. 3, pp. 23-36, 2010.

[9] I. Pihlatie, "Comparison of static chamber to measure $\mathrm{CH}_{4}$ emission," Soil Agriculture and Forest Meteodology, pp. 171-172, 2013.

[10] M. T. Trinh and T. V. The, "An estimation of GHG reduction potential for agricultural sector in Vietnam. Hanoi, Vietnam," Project Report from Institute for Agricultural Envirmonent (IAE)and UNDP, Hanoi, Vietnam, pp. 45-50, 2012.

[11] J. Liu, H. J. Zhang, and L. S. Pereira, "Model validation and crop coefficients for irrigation schedualing in the North China Planin," Agricultural Water Manage, vol. 36, pp. 233-246, 1998.

[12] P. Forster, V. Ramaswamy, P. Artaxo, T. Berntsen, R. Betts et al., "Changes in atmospheric constituents and in radiative forcing," The Physical Science Basis, Contribution of Working Group I to the Fourth Assessment Report of the Intergovernmental Panel on Climate Change, Cambridge University Press, Cambridge, U.K, pp. 20-25, 2007.

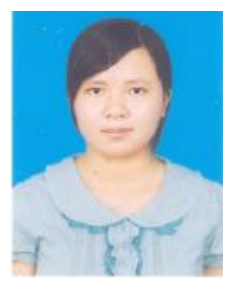

Thuy Nguyen Thu was born in 1988 in Hanoi, Vietnam. She received the bachelor degree in environmental science from Hanoi University of Science. She is a researcher in Institute for Agricultural Environment, Vietnam and now she is studying in environmental science under Japan Development Scholarship Program, Graduate School of Life and Environment Science in Tsukuba University, Japan.

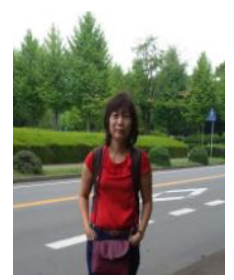

Loan Bui Thi Phuong was born in 1975 in Hatinh, Vietnam. She received the bachelor degree in environmental science from Hanoi University of Science. She is now the head of Environmental Modelling and Database Department, Institute for Agricultural Environment, Vietnam and she is a $\mathrm{PhD}$ student in Vietnam Accademy of Agricultural Science, Ministry of Agricultre and Rural Developmet. 